\title{
Identification of bacillary microbial contaminants and food poisoning agents from ukrainian plant raw materials and products
}

\section{Inna Pylypenko, Liudmyla Pylypenko , Anna Yamborko², Olena Ilyeva', Evgeniy Kotlyar ${ }^{1}$, Dmytro Babenko}

1 - Odesa National Academy of Food Technologies, Odesa, Ukraine

2 - Odesa I. I. Mechnikov National University, Odesa, Ukraine

Keywords:

Bacilli,

Food

Safety

B. cereus

PCR

Phenotypic

Article history:

Received 16.01.2017

Received in revised

form 14.03.2016

Accepted 30.03.2017

Corresponding

author:

Liudmyla Pylypenko

E-mail:

1.n.pylypenko@ukr.net

DOI: $10.24263 / 2304-$

974X-2017-6-1-3

\section{Abstract}

Introduction. The characteristics of biological contaminants occurring in plant food products, such as foodborne infections and poisonings, causative agents of spoilage, accelerated indication of potential danger to the consumer are of scientific and practical importance.

Materials and methods. A row of widespread and industrially grown kinds of vegetables, fruits, berries and a number of canned and dried products and spices were investigated. Morphological, cultural and biochemical properties of the isolated cultures were studied by conventional methods. Polymerase chain reaction (PCR) was performed using groupspecific and species-specific primers to bacillary sequences with electrophoresis of PCR products in $1.5 \%$ agarose gel.

Results and discussion.Bacillary microbial contaminants and potential causative agents of food poisoning and food spoilage, which are common in industrially processed types of vegetable raw materials (vegetables, fruits, berries and products of their processing) in Ukraine, have been investigated. The dominance of the subtilis-licheniformis morphotypes of the order Bacillales among the detected rod-shaped spore-forming microorganisms is a feature of the Ukrainian vegetative raw materials. The composition of microbiota of various types of vegetable raw materials and products of their processing were studied by the complex of their phenotypic and moleculargenetic properties. The long duration and potential inaccuracy of identification of aerobic and facultative-anaerobic spore-forming bacteria by the complex of their phenotypic properties has been showed. The method of preparation of food samples and PCR with group-specific and species-specific primers for speeding-up diagnostics of $B$. cereus, Paenibacillus polymyxa, P. macerans strains in samples have been tested. Contamination of samples of plant raw materials and products of their processing by epidemiologically significant microorganism $B$. cereus were examined, and showed levels from $16.7 \%$ in fresh fruits to $72.7 \%$ in spices from the total number of samples.

Conclusions. The bacillary microbial contaminants were identified and a speeded up method of food samples preparation for PCR to detect regulated bacillary microorganisms that affect product safety was tested. 


\section{Introduction}

The assessment of food safety in modern conditions is relevant all over the world [1,2], as an important characteristic of the quality of nutrition is becoming increasingly important due to increasing pollution [3], and microbiological hazards as a priority in assessing the degree of risk are due to the presence of regulated microorganisms in food. Being criterial in the system of indicators of safety and quality of food, microbiological contaminants also characterize the suitability of products for use [4, 5]. Besides, the qualitative and quantitative composition of the microorganisms of raw materials, along with its biochemical properties, determines the types, methods and regimes of technological processing [6,7].

The deterioration of the man-made environment associated with urbanization, climatic and geographic and environmental conditions of man, reducing its immunoreactivity and affecting the individual microecosystems, actualizes the need for strict control of food safety and the development of modern accelerated methods for detecting microorganisms. When processing vegetable raw materials, particularly canned food, the quality and safety of the finished product depends on the quality of the processed raw materials and is determined by the absence of microorganisms and their toxins that are dangerous to human health or changing their nutritional value $[1,8,9]$. In the Codex Alimentarius CAC / GL 21 document, a number of EU policy documents - the report of the EU Commission, EU guidance document 2073 - and the documents of the Federal Food and Drug Administration provide general information on the principles for the development and application of microbiological criteria for different types of food products $[10,11,12]$.

Among the aerobic and facultative anaerobic spore-forming bacteria of the Bacillales order [13], the genus Bacillus is one of the largest and most common, currently includes 268 species and 7 subspecies [14], among which are the causative agents of human foodborne illness and food spoilage [15-18]. The study of the quantitative and qualitative composition of the microbial population of fruits, vegetables, berries, and especially their thermally stable species, underlies the development of technological solutions for preserving the native properties of plant raw materials before processing and guaranteeing product safety for the consumer.

The abundance of microorganisms that make up the microbiota of plant raw materials, the duration and inaccuracy of the identification of individual species of bacilli by traditional methods of research, actualize the development of speeded up methods of detecting pathogenic species that affect product safety. Therefore, the characteristics of biological contaminants occurring in plant food products - agents of foodborne infections and poisonings, accelerated indication of potential danger to the consumer, development of speeded up and reliable methods for controlling the safety of products are of scientific and practical interest.

Thus, the goal of the research is the identification of aerobic and facultative anaerobic spore-forming bacteria of raw materials - fruits, vegetables, berries and products of their processing, and an accelerated assessment of the safety of plant products in relation to bacillary microbial agents of food poisoning of humans and spoilage of products. 


\section{Materials and methods}

\section{Microorganisms}

Researches of widespread and industrially grown kinds of vegetables, fruits, berries, in particular, green peas, beetroot, tomatoes, carrots, apples, pears, plums, peaches, dill, spinach, parsley, strawberry, a number of canned and dried products, and also spices. Samples of raw materials were selected according to standardized selection rules for the average sample $[9,20]$ immediately after the raw material was delivered for processing, the processed products in packed, dried or canned form - after inspecting batches, paying special attention to possible defective samples. Each sample was tested in triplicate.

Bacterial strains used in this study were obtained from the National Collection of Type Cultures from Institute of Microbiology and Virology D.K. Zabolotny of NAS of Ukraine, State institution "Ukrainian Centre for Disease Control and monitoring of the Ministry of Health of Ukraine", Scientific Research Institute of preventive toxicology and disinfection of the Ministry of Health of Ukraine, Collections of Type Cultures of Odesa National Academy of Food Technologies and Odesa I. I. Mechnikov National University and were used as a control strains. They are Bacillus cereus ATCC 11778, B. cereus ATCC 10702, B. licheniformis C, Paenibacillus macerans B $5803^{\mathrm{T}}$, P. polymyxa B $5760^{\mathrm{T}}$, B. coagulans B $5850^{\mathrm{T}}$, Geobacillus stearothermophilus UCM B 718, and 117 strains isolated from food samples of edible raw material and products.

\section{Determination of phenotypic properties}

For the analysis, flushing or shredded samples of an average raw material sample were used which were heated for 20 minutes at a temperature of $(80 \pm 1)^{\circ} \mathrm{C}$ and after cooling to room temperature were plated onto meat-peptone agar (MPA) and incubated at a temperature of $30 \pm 1{ }^{\circ} \mathrm{C}$ for $24-48$ hours $[9,21]$. Samples of dried or canned products were examined without additional heating. To account for the total number of bacteria in the raw material, the samples were also inoculated without heating. Mesophilic aerobic and facultative anaerobic bacteria (MAFAnM) were taken into consideration for inoculation for MPA.

Morphological, cultural and biochemical properties of the isolated cultures were studied by conventional methods on the basis of: the growth pattern on solid and liquid nutrient media (MPB, MPA, MPA enriched with starch, nitrates, etc.), saccharolytic properties - by inoculation of semi-liquid Giss' media, proteolytic properties by inoculation of milk, and meat-peptone gelatin (MPG), determination of indole - by paper indicator impregnated with oxalic acid solution, catalase - by reaction with hydrogen peroxide, production of acetoin - by reaction with egg yolk, hemolytic activity - by the ability of microorganisms to break hemoglobin by direct inoculation of culture on blood agar [7, 9, $20-22]$. A quantitative characteristic was established as the proportion (\%) of bacillary species of microorganisms from the total number of detected contaminants.

\section{DNA extraction and PCR}

PCR was performed using group-specific and species-specific primers to bacilli sequences according to Park et al. [23]. DNA was isolated from the samples using the SureFast ${ }^{\circledR}$ PREP Bacteria F1021 (CONGEN, Germany). The composition of the mixture for PCR: 10x PCR buffer (reaction buffer for amplification, optimized for highly specific PCR, designation 10x implies dilution factor by other additive components of the reaction mixture) - $2 \mu \mathrm{l}, \mathrm{MgCl}_{2}$ solution with a molar concentration of $0.05 \mathrm{~mol} / \mathrm{l}-0,8 \mu \mathrm{l}$, a solution 
of dNTPs with a molar concentration of $0.0025 \mathrm{~mol} / \mathrm{l}$ of $1.6 \mu \mathrm{l}$, a Taq polymerase solution with an enzymatic activity of $5 \mathrm{U} / \mu \mathrm{l}$ is $0.4 \mu \mathrm{l}$. Reagents from Fermentas (Latvia) were used. The supernatant containing DNA was introduced into the reaction mixture in a volume of 5 $\mu \mathrm{l}$.

The following pair of group-specific oligonucleotide primers for the groEL gene was used, which is characteristic for all representatives of the Bacillus cereus group and 3 pairs of species-specific primers for individual microorganisms, namely:

to B. cereus group BCGSH - 1F GTGCGAACCCAATGGGTCTTC groEL BCGSH - 1R CCTTGTTGTACCACTTGCTC;

to $B$. thuringiensis type BTJH - 1F GCTTACCAGGGAAATTGGCAG $\quad$ gyrB BTJH - 1R ATCAACGTCGGCGTCGG;

to $B$. cereus type nhe A F AAGGCGAATGTACGAGAGTGG nhe A nhe A R CTTCTCTCGTTTGACTATCTGCAG;

to Paenibacillus polymyxa type 29Pp F GAGCGGGGTTGATTAGAAGC 179Pp R CTTTCCTCCTTCTCCCATGC ;

to Paenibacillus macerans type MAC 1 ATCAAGTCTTCCGCATGGGA MAC 2 ACTCTAGAGTGCCCAMCWTT.

PCR cycles are primary denaturation at $94{ }^{\circ} \mathrm{C}$ for $5 \mathrm{~min}, 30$ cycles of denaturation at $94{ }^{\circ} \mathrm{C}$ for $30 \mathrm{~s}$, annealing at $63{ }^{\circ} \mathrm{C}$ for $30 \mathrm{~s}$, elongation at $72{ }^{\circ} \mathrm{C}$ for $30 \mathrm{~s}$, final elongation at $72{ }^{\circ} \mathrm{C}$ for $5 \mathrm{~min}$ (Thermal cycler with BioRad software, USA). Primers were chosen on the basis of literature data [23-25] and synthesized by SPC "Simesta VAAL" (Odesa, Ukraine).

As a negative PCR control, deionized water was used to control the purity of the reagents. A visual evaluation of the size of the formed amplicons was carried out using molecular weight markers.

Electrophoresis of PCR products was carried out in a 1.5\% agarose gel. Trisacetate buffer was used (Equipment for electrophoresis of PCR products from BioRad, USA). DNA was stained with ethidium bromide $(0.5 \mu \mathrm{g} / \mathrm{ml})$ and photographed with a video system (BioRad, USA) under UV light (wavelength $312 \mathrm{~nm}$ ).

\section{Results and discussion}

\section{Phenotypic identification of bacillary contaminants}

The composition of microorganisms of food raw materials and products characterizes both the possibility of epidemiological risk and high-quality products. Table 1 presents a description of the morphophysiological and biochemical properties of 69 isolated strains of bacilli, the presence of spores in which does not modify the vegetative cell, and utilizing arabinose, mannitol and xylose with acid formation without gas (6 morphotypes). These cultures had the following general properties: medium-sized sticks $(0.6-0.8)$ x (1.5-3.0) $(1.0-1.2) \times(3.5-5.0) \mu \mathrm{m}$ with elliptical spores located centrally and not exceeding the size of the cells. Also of them are gram positive; 25 isolates had pronounced mobility in diurnal culture. 
Table 1

Description of the acid-forming bacilli of vegetable raw material and products

\begin{tabular}{|c|c|c|c|c|c|c|}
\hline \multirow{2}{*}{ Characteristics } & \multicolumn{6}{|c|}{ Properties of bacilli by morphotypes } \\
\hline & I & II & III & IV & $\mathbf{V}$ & VI \\
\hline $\begin{array}{l}\text { Number of isolates } \\
\text { taken for } \\
\text { identification }\end{array}$ & 20 & 16 & 6 & 12 & 10 & 5 \\
\hline Cell sizes, microns & $\begin{array}{r}(0,7-, 8) \times \\
(2,0-3,0) \\
\end{array}$ & $\begin{array}{c}(0,6-0,8) \times \\
(1,5-2,0)\end{array}$ & $\begin{array}{l}(0,6-0,7) \times \\
2,0-2,5)\end{array}$ & $\begin{array}{c}(1,0-1,2) \times \\
(3,0-4,0)\end{array}$ & $\begin{array}{c}(1,0-1,2) \times \\
(3,0-4,0) \\
\end{array}$ & $\begin{array}{c}(1,2-1,5) \times \\
(2,5-3,0)\end{array}$ \\
\hline $\begin{array}{l}\text { Growth on MPA in } \\
\text { anaerobic conditions }\end{array}$ & - & + & - & + & + & - \\
\hline Hydrolysis of starch & + & + & - & + & $\begin{array}{l}+9 \text { cultures } \\
-1 \text { culture }\end{array}$ & + \\
\hline $\begin{array}{l}\text { Reduction of } \\
\text { nitrates }\end{array}$ & + & + & - & + & + & + \\
\hline $\begin{array}{l}\text { Decarboxylation of } \\
\text { tyrosine }\end{array}$ & - & - & - & + & $\begin{array}{l}+8 \text { cultures } \\
\pm 2 \text { cultures }\end{array}$ & + \\
\hline Hemolytic activity & - & - & - & + & + & - \\
\hline Lecithinase activity & - & - & - & + & + & - \\
\hline $\begin{array}{l}\text { The reaction of Vo- } \\
\text { ges-Proskauer (pro- } \\
\text { duction of acetoin) }\end{array}$ & + & + & + & + & + & - \\
\hline $\begin{array}{l}\text { Production of acid } \\
\text { from arabinose, } \\
\text { xylose, mannitol }\end{array}$ & + & $\begin{array}{l}\mathrm{A}+ \\
\mathrm{G} \pm\end{array}$ & + & - & - & $\begin{array}{l}+3 \text { cultures } \\
-2 \text { cultures }\end{array}$ \\
\hline Intended view & $\begin{array}{l}\text { Bacillus } \\
\text { subtilis }\end{array}$ & $\begin{array}{l}\text { Bacillus } \\
\text { licheni- } \\
\text { formis }\end{array}$ & $\begin{array}{l}\text { Bacillus } \\
\text { pumilis }\end{array}$ & $\begin{array}{l}\text { Bacillus } \\
\text { cereus }\end{array}$ & $\begin{array}{l}\text { Bacillus } \\
\text { thurin- } \\
\text { giensis }\end{array}$ & $\begin{array}{l}\text { Bacillus } \\
\text { mega- } \\
\text { terium }\end{array}$ \\
\hline
\end{tabular}

All cultures have an aerobic type of respiration (catalase-positive), but 38 of them also showed the ability to grow on MPA under anaerobic conditions. Of the other common properties, all isolated cultures with varying degrees of intensity exhibited the ability to liquefy gelatin, hydrolyse casein, assimilate glucose, lactose, sucrose to produce acid without gas production, but only 45 of them developed on media with mannitol, xylose or arabinose. To the utilization of tyrosine, the ability was detected in 27 isolated cultures, for two it was not established reliably. With the exception of six isolates, all reduced nitrates to nitrites. Twenty-two cultures showed lecithinase activity.

Determination of the proportion of isolated acid-forming bacilli from the identified (\%) allows them to be arranged in descending order in the following order: Bacillus subtilisBacillus licheniformis $>$ Bacillus cereus $>$ Bacillus megaterium $>$ Bacillus pumilis $\geq$ Bacillus thuringiensis.

According to the totality of the morphological and cultural features of the isolated cultures of the first and second morphotypes studied by us, it can be concluded that, with a common coincidence of most of the individual indices, they differ among themselves by few (the relief of the colonies - representatives of the I morphotype on the MPA formed small grayish shiny colonies and II morphotypes - blurred; representatives of the first 
morphotype, when sown with a prick, gave crater-like liquefaction of gelatin, representatives of the second morphotype were saccular, and representatives of the I and II morphotypes opacity and thin film were formed on MPB, but in the second case, the broth was cleared, the representatives of the first morphotype alkalized the milk during peptonization) and can be combined into the group subtilis-licheniformis. These cultures accounted for the largest proportion of bacilli found on raw materials. It is these microorganisms that most often constitute the permissible aerobic microbiota of heattreated benign products intended for long-term storage [20].

From Table 1 description it becomes created that bacillus of the subtilis-licheniformis group, six cultures from the third morphological group were distinguished by smoother, whitish shiny colonies on MPA growing into a substrate, formation of a thin film on the MPB, and opacity, peptonization of milk without clotting; crater-like liquefaction of gelatin during inoculation in a stalk, lack of amylase and tyrosinase activity and the ability to reduce nitrates. Presumably they were attributed to the species Bacillus pumilis, whose number was insignificant and amounted to no more than $10.8 \%$ of the total number of bacilli that contaminated the investigated raw materials.

In the fourth group of cultures, smooth grayish-white colonies formed on the MPA, caused an opacity of the MPB and the formation of a sediment, did not change the kind of milk, did not liquefy gelatin when planted with a prick, forming a brilliant coating on the surface. They split maltose, did not split mannitol. In the early stages of growth on glucose agar, the cells contained fat globules. Disputes formed quickly. All cultures exhibited lecithinase activity on the yolk agar, formed acetoin and characteristic ruby colonies on salt agar with 2,3,5-triphenyltetrazolium chloride, as well as indole, which confirmed their difference from $B$. pumilis and microorganisms of the subtilis-licheniformis group. This allowed us to define them as $B$. cereus. On the types of plant raw materials studied, $B$. cereus varieties comprised between 8.5 and $29 \%$ of the total number of bacilli.

Colonies of group $\mathrm{V}$ bacilli are roundish, greyish-white, with a pasty consistency, a matte surface, like B.cereus, with a slightly-wavy margin. Presumably, this group can be formed by strains of $B$. thuringiensis. On the investigated vegetables, $B$. thuringiensis species were small, but prevailed on parsley and spices.

An important reference point in the identification of group VI bacilli was the size, cell structure, folded macrorelief of the colony, which differentiate them from the species described above. Colonies on MPA are round, thick, convex, whole, shiny, slimy. With the age of the culture, the substrate is colored brown. On the MPB, the growth is meager in the form of haze, forming a greyish surface coating on the gelatinous media, when planting with a stab in the column - liquefaction in the form of a crater. Milk does not roll, peptonizes. In old cultures, the growth in MPA revealed fat. Representatives of the sixth group were identified as B. megaterium. Reactions of tyrosine cleavage and reduction of nitrates varied depending on the age of the culture. The heat-resistant strains of these bacilli in the samples were also small: $4-14 \%$.

The bacilli described in Table 2, are gram-positive mobile rods whose spores are larger in diameter than the thickness of the cells and are subterminal or terminal. They form catalase, but are able to grow on MPA under anaerobic conditions, and also hydrolyze starch, casein, reduce nitrates to nitrites, do not form indole, lecithinase and tyrosinase. In contrast to the bacilli described in Table. 1, when cultivated on media with arabinose, xylose and mannitol form a gas along with the acid.

The group of bacilli VII is made up of microorganisms that grow poorly on MPA with the formation of thin round beige widespread colonies. They cause turbidity of the MPB and form a mucous precipitate. The Gram-staining of cells during cultivation on different 
media showed variability. These bacilli do not decarboxylate tyrosine and do not form acetylmethylcarbinol, liquefy gelatin. On a gelatinous medium, a weak surface coating is formed, they do not cause liquefaction during seeding. Starch hydrolyzed completely - to mono- and disaccharides. Milk coagulate with the formation of gas, utilize glucose, lactose, maltose to form acid. The complex of the revealed properties of this group basically coincides with the description of bacilli of the species B. macerans (formerly called $B$. aerosporus), which are currently reported to be of the genus Paenibacillus [26].

Table 2

Description of the acid- and gas-forming bacilli of vegetable raw material and products

\begin{tabular}{|l|c|c|c|}
\hline \multirow{2}{*}{\multicolumn{1}{|c|}{ Characteristics }} & \multicolumn{3}{c|}{ Properties of bacilli by morphotypes } \\
\cline { 2 - 4 } & VII & VIII & IX \\
\hline $\begin{array}{l}\text { Number of isolates selected for } \\
\text { identification }\end{array}$ & 15 & 19 & 14 \\
\hline Cell sizes, microns & $\begin{array}{c}(0,5-0,6) \times \\
(3,0-4,0)\end{array}$ & $\begin{array}{c}(0,6-0,7) \times \\
(2,0-3,5)\end{array}$ & $\begin{array}{c}(0,7-1,0) \times \\
(2,0-3,0)\end{array}$ \\
\hline Hydrolysis of casein & - & + & + \\
\hline Gelatin liquefying & + & \pm weak reaction & \pm \\
\hline Production of acetoin & - & + & - \\
\hline Decarboxylation of tyrosine & - & - & - \\
\hline Intended view & $\begin{array}{c}\text { Paenibacillus } \\
\text { macerans }\end{array}$ & $\begin{array}{c}\text { Paenibacillus } \\
\text { polymyxa }\end{array}$ & $\begin{array}{c}\text { Bacillus } \\
\text { circulans }\end{array}$ \\
\hline
\end{tabular}

A distinctive feature of the Bacillus group VIII is the formation of mucus on dense and liquid substrates and slow liquefaction of gelatin. On MPA form grayish shiny large colonies, on the MPB - turbidity, sediment, surface film of grayish color. Milk does not coagulate, does not form an indole. The starch is hydrolyzed, gelatin liquefies slightly (baglike liquefaction). These bacilli can presumably be attributed to varieties of $P$. polymyxa.

Group IX was made up of bacilli, which form thin spreading colonies on the surface of the MPA. Causes mild turbidity of the MPB and mild acid formation in milk (slow coagulation). On gelatinous media grow in the form of a slight surface coating, when inoculation with a prick growth was absent. Glucose, lactose, sucrose is digested with the production of acid. Three isolates in this group after growing on different substrates stained Gram variably, the rest - positively. By the type of respiration they are classified as facultative anaerobic microorganisms. They do not form acetoin, slowly dilute gelatin, hydrolyze casein. According to most of the characteristics, the description corresponds to B.circulans, a number of strains which belong to the genus Paenibacillus [27]. This species is considered mesophilic, but the literature notes the presence of thermophilic variants [1].

Detection of bacilli VII-IX morphotypes in raw materials draws attention to the need for their control in packaged products and after heat treatment (in particular, preserves, canned food) as potential causative agents of bomb damage.

Acid-forming and gas-forming bacilli on the studied raw materials are represented by a relatively small amount - from $2-4 \%$ on strawberries to $15 \%$ on green peas from the total number of allocated bacilli.

It should be noted that the morphophysiological, cultural and biochemical properties of the studied cultures did not always show convincingly. On different media, some R-form colonies transformed into S-form colonies, which made it difficult to identify themselves by 
culture and tinctorial characters. Identification difficulties prevented the introduction of the characteristics of some crops into tables and clearly determined the proportion of isolates studied in the total number of bacilli found on the raw materials examined. As studies have shown, the precise identification of bacillary species of microorganisms by classical methods is not only time-consuming, laborious, but often difficult to accurately identify.

\section{PCR detection of $B$. cereus in food samples}

Since the microorganisms of the $B$. cereus group cause foodborne illnesses and are potentially enterotoxigenic for humans, the ability to rapidly detect $B$. cereus in food is critical $[1,5-7,23,28]$.

To choose more efficient pretreatment method of raw samples and products for detection of enterotoxin-producing B. cereus, samples were inoculated with the culture of each test strain of bacilli and further experiments with DNA release from strains $B$. cereus ATCC 11778, B. cereus ATCC 10702, B. cereus UCM B 5650 and B. cereus UCM B 5671 were carried out in three variants: inoculated bacteria samples without pretreatment (wells $7,9,10)$, and the samples previously centrifuged to remove organic residues and filtered through «Millipore» nitrocellulose membrane filters (wells 1, 4), and the samples centrifugated twice in developed modes (wells 3, 11, 12, Figure 1).

It was revealed that pre-treatment of samples is desirable for the detection of toxinproducing B. cereus in plant raw materials and products using PCR: on the electrophoregram the amplicons that were formed in the case of filtering were more clear, however, preliminary preparation with double centrifugation was most effective (Figure 1).

Thus, the method of preliminary treatment of samples of plant raw materials and products with double centrifugation: the first - to remove the residues of organic substances of the product and the second for the concentration of microorganisms. Sampling regimes have been submitted for priority and they have been used for further research.

To confirm the specificity of PCR, the B. cereus strain UCM B 5671 was tested with the nhe primer to the enterotoxigenic gene nhe $A$ (well 17). The size of the amplicon formed was $553 \mathrm{bp}$. Thus, by the PCR method, the ability to form an amplicon at $400 \mathrm{bp}$ to the gene groEL, which is characteristic for all representatives of $B$. cereus group.

$B$. cereus causes diarrhea and emetic syndromes, producing various extracellular toxins, including the three main types of enterotoxins, namely hemolysin BL $(h b l)$, nonhemolytic enterotoxin (nhe) and cytotoxin $\mathrm{K}($ cyt $K)$ [13].

Among the strains of $B$. cereus, enterotoxigenic genes $h b l A$, nhe $A$, cyt $K$ and $F m$ (enterotoxin FM) were widely spread. However, we selected only the nhe $A$ gene for PCR, given its greatest prevalence and detectable toxicity, which is associated with a major role in food poisoning. The polymerase chain reaction with specific primers nhe A F and nhe A $\mathrm{R}$, matched to the site of the $n h e A$ gene, confirmed the belonging of all tested collection strains of B. cereus to the enterotoxigenic species of B. cereus, whereas in PCR analysis of the DNA of the collection species G. stearothermophilus and P. polymyxa and in negative control (PCR mixture without DNA), no amplification products were detected. The size of the amplicons was $553 \mathrm{bp}$, which indicated the proper specificity of the PCR.

PCR results with product samples containing different combinations of bacterial strains using specific species-specific primers are shown in Figure 2. 


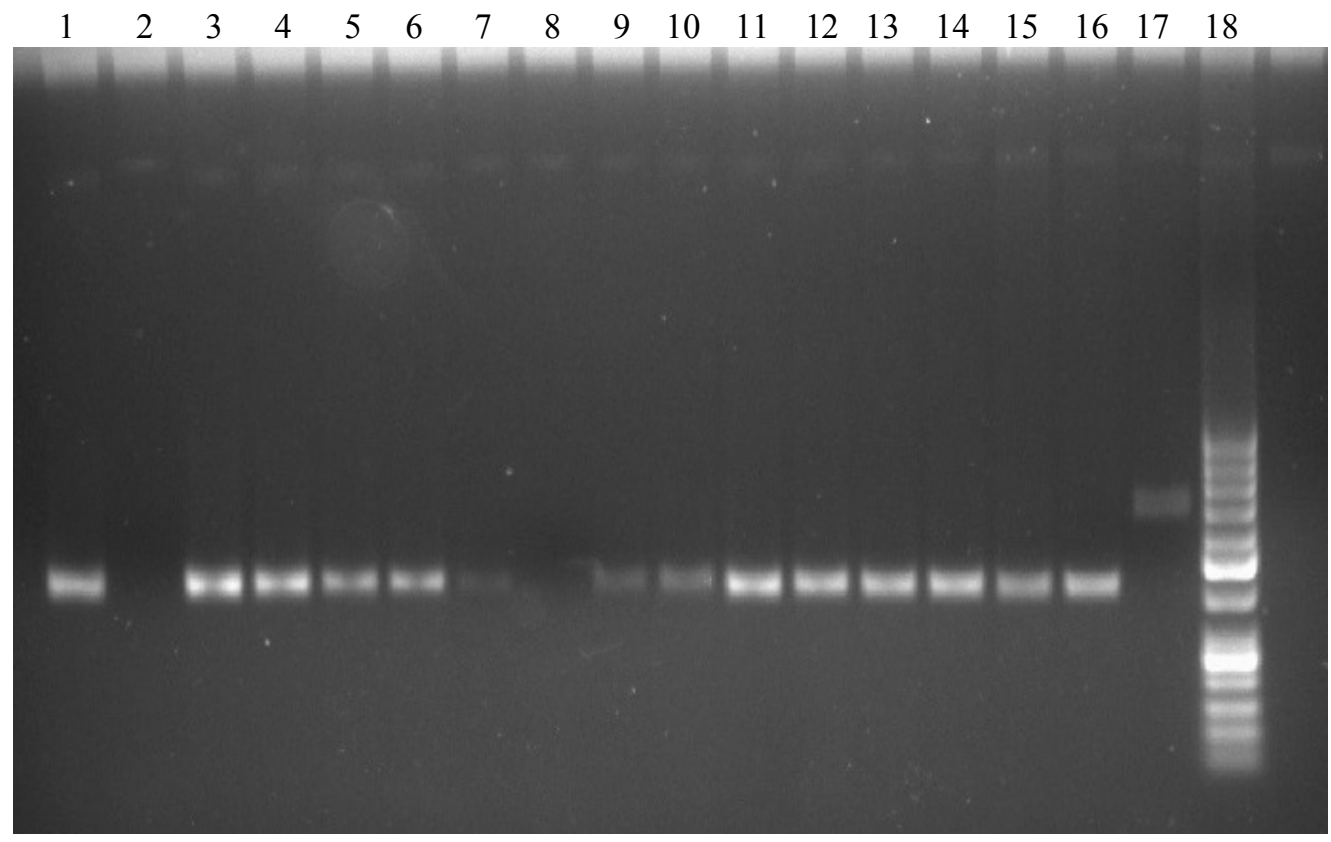

Figure 1. Electrophoregram of PCR products with DNA of strains of Bacillus spp. with a pair of specific oligonucleotide primers to the gene groEL:

1. B. cereus UCM B 5671 (using a membrane filter)

2. Negative PCR control;

3. B. cereus ATCC 11778 (using centrifugation)

4. B. cereus ATCC 10702 (using centrifugation)

5. B. cereus UCM B 5650 (using a membrane filter)

6. B. cereus UCM B 5671 (using a membrane filter)

7. B. cereus UCM B 5671 (without filtration)

8. Do not inoculate bacteria from cans;

9. B. cereus ATCC 11778 (without filtration)

10. B. cereus ATCC 10702 (without filtration)

11. B. cereus $\mathrm{P} 90-1$ (using centrifugation)

12. B. cereus $\mathrm{P} 90-4$ (using centrifugation)

13. B. cereus $\mathrm{P} 90-9$ (using centrifugation)

14. B. cereus L-3 (using centrifugation)

15. B. cereus L-6 (using a membrane filter)

16. B. cereus L-7 (using a membrane filter)

17. B. cereus UCM B 5671 with the primer nhe A;

18. Molecular weight markers (pBR322 / BsuRI, Fermentas). 


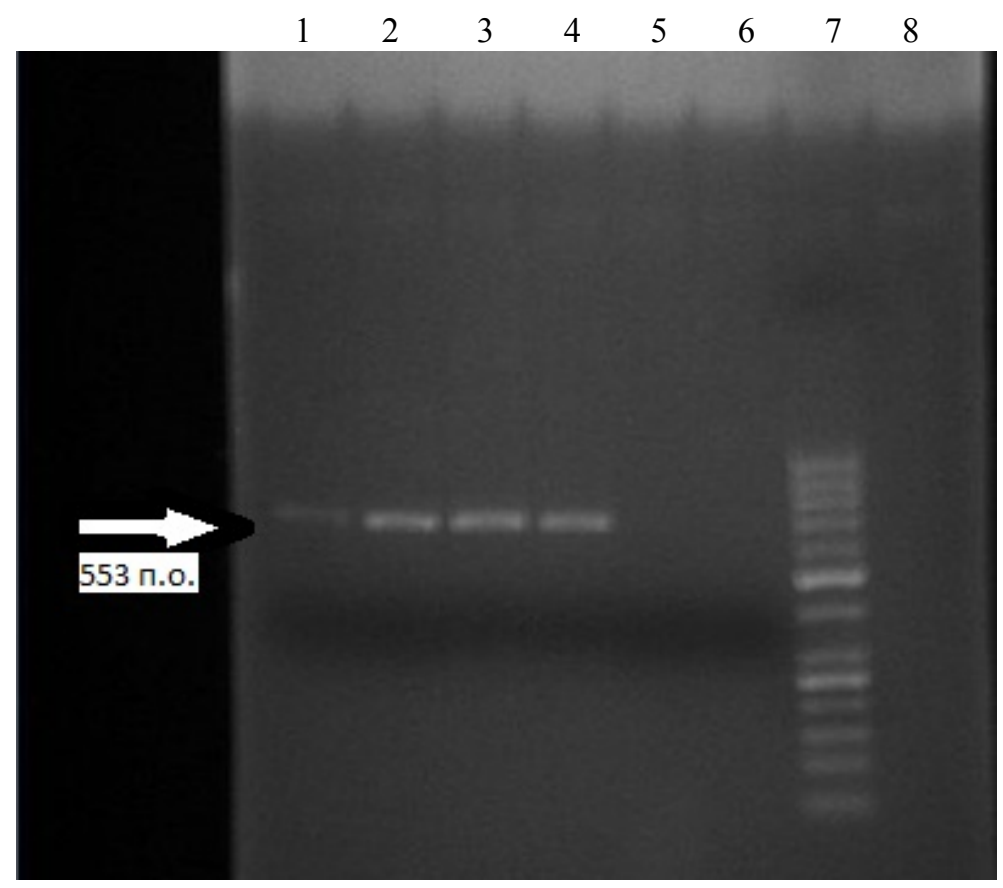

Figure 2. Electrophoregram of PCR products with DNA strains of $B$. cereus, $P$. polymyxa, $P$. macerans, $E$. coli, $S$. aureus, $C$. perfringens, $G$. stearothermophilus species with a pair of specific oligonucleotide primers to the nhe $A$ gene:

1. A mixture of B. cereus strains (B. cereus ATCC 11778, B. cereus ATCC 10702, B. cereus UCM B 5650, B. cereus UCM B 5671);

2. A mixture of strains of B. cereus, P. polymyxa and P. macerans (P. macerans B 5803 ${ }^{\mathrm{T}}$, P. polymyxa B $5760^{\mathrm{T}}$, B. cereus ATCC 11778 , B. cereus ATCC 10702, B. cereus $\mathrm{UCM}$ B 5650, B. cereus UCM B 5671);

3. A mixture of $B$. cereus and $P$. polymyxa strains $\left(P\right.$. polymyxa $\mathrm{B} 5760^{\mathrm{T}}$, B. cereus ATCC $11778, B$. cereus ATCC 10702, B. cereus UCM B 5650, B. cereus UCM B 5671); 4. A mixture of $B$. cereus and $P$. macerans strains $\left(P\right.$. macerans $\mathrm{B} 5803^{\mathrm{T}}, B$. cereus ATCC 11778, B. cereus ATCC 10702, B. cereus UCM B 5650, B. cereus UCM B 5671);

5. C. perfringens and G. stearothermophilus UCM B 718;

6. Staphylococcus aureus ONU 223;

7. Molecular weight markers (pBR322 / BsuRI, Fermentas);

8. Escherichia coli UCM B 906.

Primers nhe A F and nhe A R formed an amplicon sized 553 bp in PCR with B. cereus strains, primers 29Pp F, 179Pp R formed an amplicon with a size of $150 \mathrm{bp}$ with strains of the species $P$. polymyxa, primers MAC 1, MAC 2 formed an amplicon with a size of $100 \mathrm{bp}$ with strains of the species $P$. macerans. In PCR using the DNA of gram-negative bacteria Escherichia coli UCM B 906 and gram-positive bacteria Staphylococcus aureus ONU 223, $C$. perfringens and G. stearothermophilus UCM B 718, which were conducted to verify the authenticity of the results of detection of natural contamination of specimens by food poisoning and product damage agents, no amplification product was obtained. The results of detection of strains of the $B$. cereus species by the presence of the nhe $A$ gene in the studied plant products are shown in Table 3. 
B. cereus contamination of plant raw materials and products of their processing

\begin{tabular}{|l|c|c|c|}
\hline \multicolumn{1}{|c|}{ Product type } & $\begin{array}{c}\text { Number of } \\
\text { samples, } \mathbf{n}\end{array}$ & $\begin{array}{c}\text { Number of samples } \\
\text { that contain } \\
\text { B. cereus }\end{array}$ & $\begin{array}{c}\text { Proportion of } \\
\text { contaminated samples, } \\
\text { \% }\end{array}$ \\
\hline Fresh fruit & 12 & 2 & 16,7 \\
\hline Fresh berries & 9 & 3 & 33,3 \\
\hline Fresh vegetables & 34 & 21 & 61,8 \\
\hline $\begin{array}{l}\text { Canned food with signs } \\
\text { of spoilage }\end{array}$ & 9 & 4 & 44,4 \\
\hline Dried vegetable mixes & 16 & 7 & 43,7 \\
\hline Spices & 11 & 8 & 72,7 \\
\hline Dried herbs in & 14 & 10 & 71,4 \\
\hline $\begin{array}{l}\text { Vegetables boiled in } \\
\text { vacuum polymer bags }\end{array}$ & 12 & 2 & 16,7 \\
\hline
\end{tabular}

Comparing the results with those given for vegetables from the city of Mexico, it is possible to note practically the same trends of detection of $B$. cereus for most types of fresh vegetable raw materials $-61.8 \%$ and $57 \%$ for the Ukrainian and Mexican regions, respectively [29]. And as noted by Valero et al. [30] in Spain, all samples of fresh raw materials - peppers, cucumbers, tomatoes, carrots, zucchini, onions - were contaminated with $B$. cereus. This, according to INFOSAN [31], leads to an increase in the incidence of foodborne illness.

\section{Conclusions}

Bacillary microbial contaminants and agents of food poisoning of plant raw materials and products of the Ukrainian region were identified. The composition of microbiota of various types of vegetable raw materials - vegetables, fruits, berries - and products of their processing were studied. A feature of plant raw materials of Ukraine is the dominance of rod-shaped spore-forming microorganisms of the Bacillales order of the group subtilislicheniformis. To accelerate the indication of the potential hazard of products for consumers, a method for preparing food samples was tested and PCR with group-specific and species-specific primers was performed in order to diagnose strains of B. cereus, $P$. polymyxa and $P$. macerans microorganisms in samples. The contamination of samples of plant raw materials and products of their processing with epidemiologically significant microorganism B. cereus were examined, and showed levels from $16.7 \%$ in fresh fruits to $72.7 \%$ in spices from the total number of samples.

\section{References}

1. Blackburn Clive de W. (2006), Food spoilage microorganisms, CRC Press.Woodhead Publishing Ltd., Cambridge, England, p. 736.

2. Kleter G.A., Parandini A., Filippi L., Marvin H.J.P. (2009), Identification of potentially emerging food safety issues by analysis of reports published by the 
European Community's Rapid Alert System for Food and Feed (RASSF), Food and chemical toxicology, 47(5), pp. 932-950.

3. Thomson B., Rose M. (2011), Environmental Contaminants in the light of Climate Change, Quality Assurance and safety of Crops \& Foods, 3, pp. 2-11.

4. Discussion Paper (2005): on strategy for setting microbial criteria for foodstuffs in Community legistration, SANCO/1252/2001, European commission health \& consumer protection directorate-general, Brussel, Rev. 11, pp. 34, Available at: http://ec.europa.eu/food/food/biosafety/salmonella/discussion_paper_en.pdf.

5. Dzhej Dzh. M., Lessner M. Dzh., Gol'den D. A. (2014), Sovremennaja pishhevaja mikrobiologija, BINOM. Laboratorija znanij, M., pp. 886.

6. Melngaile A. (2013), Microbiological risk analysis in catering establishments, Proceedings of the latvian academy of sciences. Section B, 67(N4/5(685/686)), pp. 340-349.

7. 7. Pylypenko L. N., Verhivker Ja. G., Pylypenko I. V. (2015), Konservirovanie pishhevyh produktov. Mikrobiologija, jenergetika, kontrol': monografija, «BMB», Odessa, pp. 232.

8. Craig P., Burca G. de. (2011), EU Law: Text, Cases, and Materials. Cambridge University Press, Cambridge, pp. 1304 .

9. Pylypenko Yu.D., Mazurenko I.K., Pylypenko I.V., Pylypenko L.M. (2009), Derzhavni normatyvni dokumenty na syrovynu, napivfabrykaty, materialy ta konservovanu produkciyu. Pokaznyky bezpechnosti ta yakosti (Metodychni vkazivky. Vydannya oficijne), Minagropolityky, K., pp. 114.

10. SANCO/4198/2001 (2005), Draft commission regulation of on microbiological criteria for foodstuffs. Rev. 21 (final), Commission of the european communities, Brussels, pp. 34.

11. Melngaile A. (2008), Microbiological risk analysis in public catering establishments, Summary of Doctoral Thesis, Jelgava, pp. 64.

12. Mortimore S.E., Wallace C.O. (2013), HACCP: A Practical Approach, Springer Science \& Business Media, UK, pp. 475.

13. Connor N., Sikorski J., Rooney P. et al. (2010), Ecology of speciation of the genus Bacillus, Appl. Environ. Microbiol. , 76, pp. 1349-1358.

14. (2015), Public Health England, Identification of Bacillus species, UK Standards for Microbiology Investigations, 9(3), available at://www.gov.uk/uk-standards-formicrobiology-investigations-smi-quality-and-consistency-in-clinical-laboratories.

15. Rivera A.M.G., Granum P.E., Priest F.G. (2000), Common ocurence of enterotoxin genes and enterotoxicity in Bacillus thuringiensis. FEMS Microbiol. Letter, 215, pp. $47-51$.

16. Stenfors L.P., Mayr, R., Scherer, S., and Granum, P.E. (2002), FEMS Microbiol. Letter, 190, pp. 67-72.

17. Ehling-Schulz M., Svensson B., Guinebretiere M.H., Lindbäck T., Andersson M., Schulz A., Fricker M., Christiansson A. et al. (2005), Emetic toxin formation of Bacillus cereus is restricted to a single evolutionary lineage of closely related strains, Microbiology, 151, pp. 183-197.

18. Schoeni J.L. and Wong A.C. (2005), Bacillus cereus food poisoning and its toxins, $J$. Food Prot., 68, pp. $636-648$.

19. Pylypenko Inna, Pylypenko Liudmyla, Sevastyanova Elena, Kotlyar Evgeniy, Kruchek Ruslana. (2016), Epiphytic and regulated microbial contaminants of food vegetable raw materials and products, Ukrainian Food Journal, 5(2), pp. 272-280. 
20. Persianova I.P., Gerasimenko L.N., Stojanova L.A. (2010), Mikrobiologija konservirovanija $i$ mikrobiologicheskij kontrol' konservnogo proizvodstva I.P. Persianova, Izd. «Vneshreklamservis», Odesa, pp. 310.

21. Harley J.P., Prescott L.M. (2002), Laboratory Exercises in Microbiology, The McGraw Hill Companies, N.Y., p. 466.

22. Netrusov, A.I. [i dr.]. (2005), Praktikum po mikrobiologii: ucheb. posobie dlja stud. vyssh. ucheb. zavedenij, IC «Akademija», Moscow, pp. 608.

23. Park S.H., Kim H.J., Kim J.H., Kim T.W., Kim H.Y. (2007), Simultaneous detection and identification of Bacillus cereus group bacteria using multiplex PCR, $J$ Microbial Biotechnol., 17 (7), pp. $1177-1182$.

24. Timmusk S., Paalme V., Lagercrantz U., Nevo E. (2009), Detection and quantification of Paenibacillus polymyxa in the rhizosphere of wild barley (Hordeum spontaneum) with real-time PCR, Journal of Applied Microbiology, 107, pp. 736-745.

25. Vollu R.E., Dos Santos S.C.C., Seldin L. (2003), 16S rDNA targeted PCR for the detection of Paenibacillus macerans, Letters in Applied Microbiology, 37, pp. 415420.

26. Bergey's Manual of systematic bacteriology. (2005), The proteobacteric. Part A, Bergey's Manual Trust Department of Microbiology and Molecular Genetics Michigan State University, 2, pp. 317-321.

27. ABIS Encyclopedia, available at://www.tgw1916.net/Bacillus/circulans.html

28. Chang, Y. H., Shangkuan Y. H., Lin H. C., Liu H.W. (2003), PCR assay of the groEL gene for detection and differentiation of Bacillus cereus group cells, Appl. Environ Microbiol. , pp. 4502-4510.

29. Karen A. Flores-urba N, Ivan Natividad-bonifacio, Carlos R. Va'zquez-quin ones, Carlos Va Zquez-salinas, and Elsa Irma (2014), Detection of Toxigenic Bacillus cereus Strains Isolated from Vegetables in Mexico City, Journal of Food Protection, 77(12), pp. 2144-2147, DOI: 10.4315/0362-028X.JFP-13-479

30. Valero M., Hernandez-Harrero L. A., Fernandez P. S., and Salmeron M. (2002), Characterization of Bacillus cereus isolates from fresh vegetables and refrigerated minimally processed foods by biochemical and physiological tests, Food Microbiol. , 19, pp. 491-499.

31. World Health Organization (2013), The International Food Safety Authorities Network (INFOSAN). World Health Organization, Geneva. Accessed 8 November 2013, Available at: http://www.who.int/foodsafety/fs_management/infosan/en/. 